\title{
Research on the Ways to Build the Teaching Staff of Brand Major Group
}

\author{
Hongxia Zhang* \\ Henan Institute of Economics and Trade, Zhengzhou 450018, Henan, China. \\ E-mail: 761039372@qq.com
}

\begin{abstract}
As an important part of higher education, higher vocational colleges send a large number of professional and technical personnel to the society every year, who serve all walks of life, and play an important role in the process of social construction. In recent years, the state and society have paid more and more attention to the teaching quality of higher vocational colleges. Higher vocational colleges need to build a major group of teachers to improve teaching quality to meet the needs of society, the country and students. Regarding the construction of the brand major group of teachers, this article proposes that schools need to proceed from reality, take student development as the foundation, combine the actual teaching resources of the school and the economic development of the regional chain, integrate internal and external teaching resources, and build a major group experimental training platform. At the same time, they should actively explore the market demand for talents and adjust the structure of major groups in a timely manner. The construction of a brand major group of teachers can not only promote the growth of young teachers in the teaching team, improve the teaching level of the school, but also make full use of the school's limited teaching resources, enhance students' theoretical knowledge and practical ability, and comprehensively improve the teaching quality.

Keywords: Higher Vocational School; Brand Major; Major Group; Teaching Staff;

Education is the foundation of a country. With the development of the times, the country and society are paying more and more attention to the teaching quality of higher vocational education. The most important factor affecting the quality of school teaching is the strength of the school's teaching staff, and the most important part of the teaching staff is the construction of the major group of teachers. The construction of professional teachers in higher vocational colleges not only caters to the needs of social development, but also lays a solid foundation for the society to train more talents. Since 2006, the Ministry of Finance and the Ministry of Education have put forward the Opinions on Implementing the National Demonstrative Higher Vocational College Construction Plan and Accelerating the Reform and Development of Higher Vocational Education, pointing out that 500 industry-university-research specialties with close integration, high employment rate and distinctive characteristics should be selected from 100 universities and provided with key supports, to form a major group. It is necessary for schools to vigorously develop key majors and other related majors as assistance, and build a brand major group of teachers belonging to the school.

The major group is a professional organization, and the form and method of the establishment are different from colleges, teaching and research offices, etc. Relevant departments are required to formulate a complete major group management system to divide the responsibilities of students and teaching resource management, so as to strengthen the school's education function, optimize teaching resources, reduce the contradiction between school internal management costs and benefits, and improve the quality of education.
\end{abstract}

\section{The importance of building a teaching team for the major group in higher vocational colleges}

The professional clusters of higher vocational colleges are set up to cultivate talents with certain technology and skills, and need the cooperation and support of related majors to form professional clusters. Building a school brand

Copyright @ 2020 Hongxia Zhang

doi: $10.18282 /$ le.v9i6.1328

This is an open-access article distributed under the terms of the Creative Commons Attribution Non-Commercial License

(http://creativecommons.org/licenses/by-nc/4.0/), which permits unrestricted non-commercial use, distribution, and reproduction in any medium, provided the original work is properly cited. 
major group can optimize the professional structure, build a school brand professional, and improve the level and efficiency of running a school by integrating teaching resources inside and outside the school.

\subsection{Build a major group of teachers and optimize the professional configuration}

With the continuous improvement of the economic level, China's industrial structure is continuously adjusted and upgraded, and new industries and positions are constantly emerging. Every year, vocational colleges provide a large number of high-quality talents for enterprises and society, and most of the students after graduation serve the production and management of enterprises. The level of literacy quality and skill level of students directly affects the school's reputation. With the rise of new industries, higher vocational colleges constantly update and set up new majors in accordance with social needs. However, with the increase of new majors, the problem of insufficient teachers in higher vocational colleges has become more and more prominent. At present, vocational colleges generally have scattered majors and similarities in school majors, causing a serious waste of teaching resources. The professional foundation is weak, without brand majors and characteristics, which is not conducive to the development of the school. To this end, the school should determine the core majors of the major group according to the needs of the industry, and build a major group with core competitiveness around the core majors. It is necessary to create a major group of teachers, so that higher vocational colleges can achieve success in a certain field or industry, and promote the rolling development of the major group according to market changes.

\subsection{Build a bipolar teaching team, accumulate bipolar teacher quality leaders}

At present, most vocational colleges are in a stage of rapid development. The school is expanding the enrollment every year, resulting in that the staff and quality level of teachers unable to meet the needs of the current stage. At present, the recruitment of teachers is mostly for graduates with no corporate work experience. The level of theoretical knowledge and ability of students is relatively high, but they lack practical experience, especially they cannot meet the social demand for bipolar teachers of high-quality and highly skilled personnel. In addition, schools lack excellent professional leaders. The leaders can not only affect the development direction of the major group, but also promote the development of the industry. At present, it is unrealistic to require the director of the teaching and research section to have full professional technical authority and management ability. Most of the teaching and research section directors of higher vocational colleges are mainly responsible for the communication of higher-level tasks and management of teaching work. To this end, the school should train major group managers to be the core of the implementation of professional technology and management, and build professional leaders and backbone teachers through the integration of internal and external teachers, and then form a professional teaching team to optimize resources and the major group structure, to streamline the hierarchical management of the teaching teams and improve teaching efficiency.

\subsection{Integrate social resources to maximize resource utilization}

In the process of running higher vocational colleges, a certain profession with a high employment rate and a profound school background should be regarded as the core of the major group, and the professions with the same engineering objects and technical fields should be integrated to reduce identical majors and optimize the professional structure to maximize the use of limited teaching resources to serve the teaching work, thereby comprehensively improving the comprehensive quality of students, cultivating students' core qualities, and improving the quality of school teaching. In addition, higher vocational colleges mainly cultivate students' practical ability and need a perfect training practice base. Schools should take the opportunity of building a major group to strengthen the construction of on-campus production training bases, off-campus practice bases, and fixed-post practice bases. Funds are prioritized in the construction of training bases to build a complete and advanced training system to enhance students' practical ability, thereby enhancing students' employment competitiveness and increasing the school's employment rate.

\section{Measures to build major groups in higher vocational colleges}

\subsection{Based on the regional industry chain, build a brand major group of higher vocational schools}

To build a major group in higher vocational colleges, it is necessary to thoroughly analyze and study the regional economy and industrial structure, combine the development direction of the regional economy and the actual teaching force of the school, determine the development direction of major group construction, and build the corresponding major group training platform and school-enterprise joint training. The internship mechanism can cultivate technical talents that meet the requirements of society and enterprises. In addition, schools should also pay attention to the industries and 
industrial chains with development potential, analyze the talents urgently needed for the development of the industrial chain, then plan and cultivate the major group system of the industry direction, cultivate professional talents, and fill the gap in the talent market.

\subsection{Focusing on the needs of the post group, insist on student development as the foundation, and cultivate technical compound talents}

Higher vocational colleges are different from colleges and universities. They mainly train professional skilled talents for enterprises. Therefore, they must keep pace with the times in the direction of talent training, always pay attention to the needs of corporate positions, and constantly adjust and optimize the talent training model and training objectives to make students quickly adapt to the requirements of corporate positions. In addition, when cultivating technical compound talents, it is necessary not only to strengthen students' vocational job operation ability, but also to focus on the cultivation of students' comprehensive abilities and professional core qualities. Adhere to student development as the center, it is needed to improve students' sense of acquisition while enhancing students' professional ability, to improve students' sense of responsibility, cooperation ability, innovation ability and professional integrity.

In addition, with the continuous innovation and development of science and technology, the school must ensure the stable development of the major group on the one hand, and deliver high-quality compound talents to the society. On the other hand, it is necessary to timely adjust the direction of the major group and optimize the structure of the major group, so as to adapt to the development of the society and optimize the allocation of teaching resources.

\subsection{Starting from the reality of the school, form a major group that adapts to the market}

The establishment of majors in higher vocational colleges has a corresponding historical background. The construction of a major group requires not only the existing school-running strength of the major, but also the market development prospects of each major. Building a major group around core majors with strong employment rates can accelerate the development of core majors. At the same time, support and encouragement should be given to some majors that have good prospects for development but cannot be realized in a short time, so as to provide talents in the future.

\subsection{Integrate teachers and training resources to improve the ability of co-construction and sharing}

The resource allocation of major groups should be related to social benefits and economy, and external efficiency should be emphasized, teaching equipment in schools should be strengthened, and a public technical platform for major groups should be built. In-school and off-campus training bases should be built according to major groups to reduce the input of similar teaching resources and maximize the use of social resources. In addition, the investment of the faculty should also be based on major groups, to recruit compound professional teachers, improve teachers' teaching R\&D capabilities and service capabilities, strengthen the major group construction mechanism, and form a sustainable development mechanism for school-enterprise collaboration and sharing.

\section{Conclusion}

All in all, teacher team building is a long-term and complex task that needs to be carried out step by step. It is inevitable that colleges will encounter such and other problems in the process of building a brand major group. The school must follow the principles of discovering, analyzing and solving problems, adhere to starting from reality, combine the characteristics of the regional economy and the development of the regional industrial chain, timely adjust the major group structure, integrate teaching resources such as on-campus and off-campus training practice bases and teachers, vigorously develop industry-university-research cooperation, exert its own advantages, strive to improve the international Influence, and contribute a modest force to socialist construction.

\section{References}

1. Li H. Research on the construction of the faculty of the brand major group of secondary vocational schools. Shenzhou 2018; (35): 91.

2. Hou L. Research and practice on the construction of new energy and intelligent automobile major group in higher vocational education_- Taking Yantai Automotive Engineering Vocational College as an example. Software (Education Modernization) (Electronic Edition) 2019; (3): 48, 115. 